\title{
POETRY
}

\section{The featherweight fighter}

The Nepalese refugee, seventy-eight years old, Lay before me, shrouded in a stained blanket, hiding. The subtle quivering of his head told me That the weight of my words, so much heavier Than his slight frame, had penetrated his cotton shield.

His cancer would spread, like the hungry bacteria Living in the carton of warm yogurt at his bedside. His beloved cure-all Indian curry leaves? Powerless, Like my silent pleas before the biopsy results. He is silent, so I bow my head and turn away.

Childlike, his cachectic arm reaches out Struggling to make a connection with me, With something. His life has always been Disconnected by war and geography; by powers Greater even than the odds now before him.

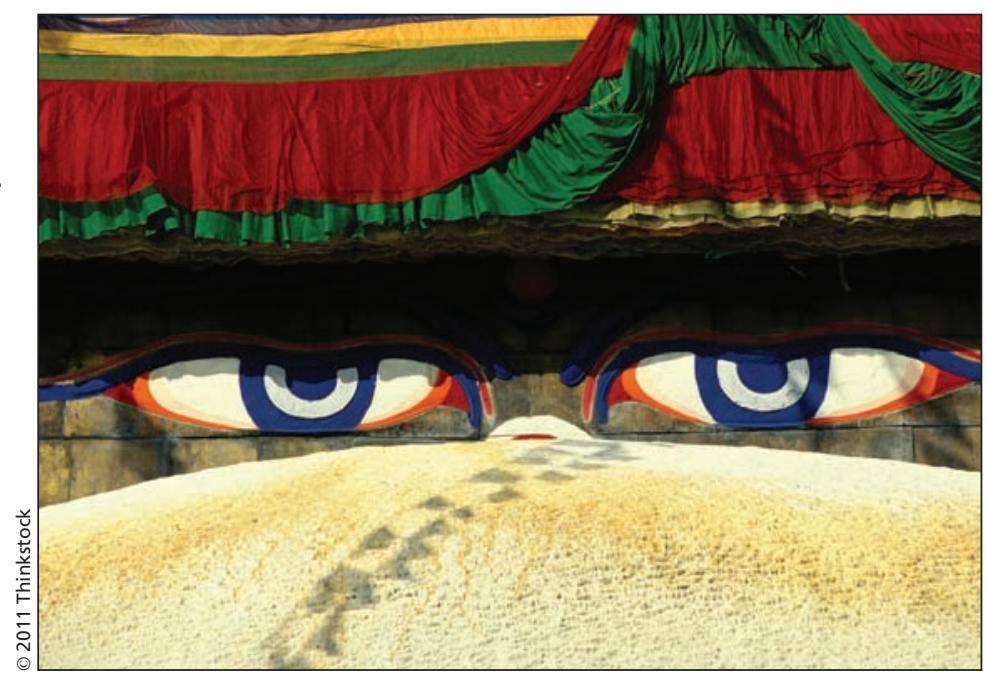

His eyes burn into mine. He will fight this, With medicine, with science, with our paradigm So foreign to his spiritual roots, which like moorings Seem to keep him from floating away on a current Of air, toward an uncertain and capricious horizon.

\section{Ryan Childers MD}

Internal Medicine, PGY-3

Department of Medicine

Johns Hopkins Bayview Medical Center

Baltimore, Md.

CMAJ 2012. DOI:10.1503/cmaj.111015 